\title{
Rockfall risk - how well do we understand the consequences of the decisions we make?
}

\author{
L. Rwodzi University of the Witwatersrand; and Seismogen Cc, South Africa
}

W. Joughin SRK Consulting, South Africa

T.R. Stacey School of Mining Engineering, University of the Witwatersrand, South Africa

\section{Abstract}

The consequences of rockfalls in the narrow tabular mining geometry typical of the gold and platinum operations in South Africa are numerous and vary depending on rockfall size and applicable remedial strategy. Rockfalls are a significant cause of mining accidents, and also result in losses to the mining operation due to such accidents as well as reduced productivity, dilution, re-supporting, and loss of sweepings. Pillars and remnants may also have to be left, which results in loss of ore, reducing the available reserves. While these financial losses can be significant, there are commonly no records of the evaluation of such losses on mines.

The financial evaluation of risk mitigation is usually tactical, being based only on the cost of implementing a support system, and does not take into account the losses resulting from accidents and incidents. The losses associated with rockfalls for different support designs are rarely quantified, hence the question, "How well do we understand the consequences of the decisions we make?" A more realistic evaluation of alternative support designs should compare the total cost of implementing the support system and the inherent risk of rockfalls. To determine the inherent risk of rockfalls, the consequences of rockfalls must be identified and quantified.

In this paper, a generic methodology to quantify the cost of the losses associated with rockfalls is proposed. The methodology was developed after extensive research was conducted on two South African narrow tabular mining operations. The methodology enables the calculation of risk associated with different support options, and the risk is expressed in monetary terms (South African rands are used in the paper), a language well understood by management. Management can therefore be involved in the design of risk mitigating systems, since they can determine the acceptable risk that the rock engineer can apply in the support design. Safety and value to the mining operation can therefore be optimised, which represents a strategic approach to rock support design rather than the tactical approach that is currently practised.

\section{Introduction}

In any engineering operation, it is imperative that structures satisfy four criteria: safety, serviceability, economics and aesthetics (Einstein, 1996). All of these factors involve both technical and non-technical uncertainties, which can affect the performance of structures. Mining takes place in a natural environment, and in any such environment variability of conditions is inherent. Variability results in uncertainty. Owing to the uncertainties that prevail within the rock engineering environment, there always exists a probability that an underground excavation will be less stable than expected (Bawden, 2008; Christian, 2004; Einstein, 2003; Stacey, 2006). Instability results in rockfalls and collapses of mine workings.

Variability and uncertainty give rise to the concept of risk, which is defined as the product of the probability of occurrence of an event and the associated consequences of the event (Vanmarcke and Bohenblust, 1982; Einstein, 1996; Summers, 2000; Einstein, 2003; Baecher and Christian, 2003; Tapia et al., 2007). Not only is risk expressed in technical terms, but it also can be combined with economic consequences and hence expressed in economic terms. 
Rock engineers are generally risk averse and their designs on mines focus on technical excellence. Designs are technical and consider only the capital and working costs of installing support in an excavation. The risk-reward relationship associated with non-performance of the support design is rarely analysed. Managers generally carry out no assessment of the consequences of support failure on costs of production and profits (Baecher and Christian, 2003; Stacey, 2006), however, making things safe costs money (Wong, 2005). It is therefore appropriate to assess the trade-off between the support design cost and the cost of the consequences of instability. This brings the concept of risk into design. Considering risk analysis in support design enables managements direct involvement in the design process. Management can define the acceptable risk, and rock engineers can then design the excavations and support to satisfy the specified risk criteria.

There is a knowledge gap regarding a clear understanding of the concept of risk, the relevant risks to mine support design and the acceptance thresholds set by management (Christian, 2004; Summers, 2000). The financial risk implication associated with rockfalls and accidents is not quantified. Quantification of such risk allows effective management, aimed at protecting the mining company, its people, assets and profits against the moral, physical and financial consequences of risk. It also allows integrated mine planning at the operational level. Further, defined acceptable risk criteria will enable motivation for increased investment in safety, as designs have to meet the set criteria.

The objectives of this paper are:

- To highlight the risk-cost approach to support design.

- To highlight the direct and indirect consequences associated with rockfalls in narrow tabular mining operations.

- To describe a methodology for quantifying the costs of the consequences of rockfalls.

- To apply the methodology on a selected mine operation as a case study.

- To demonstrate an evaluation of the overall risk-cost analysis on two different support systems under consideration for implementation.

\section{$2 \quad$ Risk in mining}

Underground support design is carried out using a variety of methods-empirical, analytical and observational methods (Swart et al., 2000). Empirical methods involve rock mass classification methods and engineering judgement. Classification methods include the $Q$ system (Barton et al., 1974), the Modified Stability Number N' (Potvin, 1998; Potvin and Hadjigeorgiou, 2001); and the MRMR system (Laubscher, 1990). Analytical methods involve closed form solutions, numerical methods and structural analyses (Swart et al., 2000). Observational methods, formalised by Peck (1969) rely on monitoring ground movement to measure instability. These methods, though widely used and well understood, are very technical and empirically derived. The concepts of risk and consequential cost are not applied in these methods (Brummer and Kaiser, 1995; Davies, 1997; Stacey, 2006; Joughin, 2008), and the consequences of support failure are not evaluated against the corresponding design.

Risk analysis has been practised in other areas of underground mining. Examples are crown pillar risk assessment (Carter and Miller, 1995), mine pillar risk assessment (Pine and Thin, 1993), risk assessment of underground excavations (Pine and Arnold, 1996) and rockfall risk analysis in coal mines (Duzgun and Einstein, 2004). However, these authors do not analyse risk inclusive of a quantitative evaluation of the consequences of failure, and therefore do not consider risk in financial terms.

In open pit mining both factor of safety (FOS) and probability of failure (POF) concepts are applied in slope design. The challenge is in selecting the permissible POF. This has been addressed by the risk-consequence $(\mathrm{R} / \mathrm{C}$ ) analysis to slope design (Contreras et al., 2006; Tapia et al., 2007; Terbrugge et al., 2006; Bawden, 2008). R/C analysis does not replace the FOS or POF approaches, but enhances them by allowing the designs to be carried out to specified acceptable risk criteria set by management. 
Owing to the success of R/C approach in slope design, a similar approach can be adopted for underground stope support design. The proposed concept is discussed in the following section.

\section{1 The risk-cost approach in underground stope support design}

In this concept, the level of risk in a stope support design takes into consideration the costs of risk control and expected costs of consequences from rockfalls. Figure 1 (adapted from Viner, 2002) illustrates the relationship between the two components. The cost of risk control is the cost of support design, implementation, monitoring and evaluation in the stope. The expected annual cost of consequences (EACC) is the product of annual frequency of rockfalls in that stope and the costs of the associated consequences. The sum of the cost of annual risk control and EACC gives the total cost of the risk for that particular stope design.

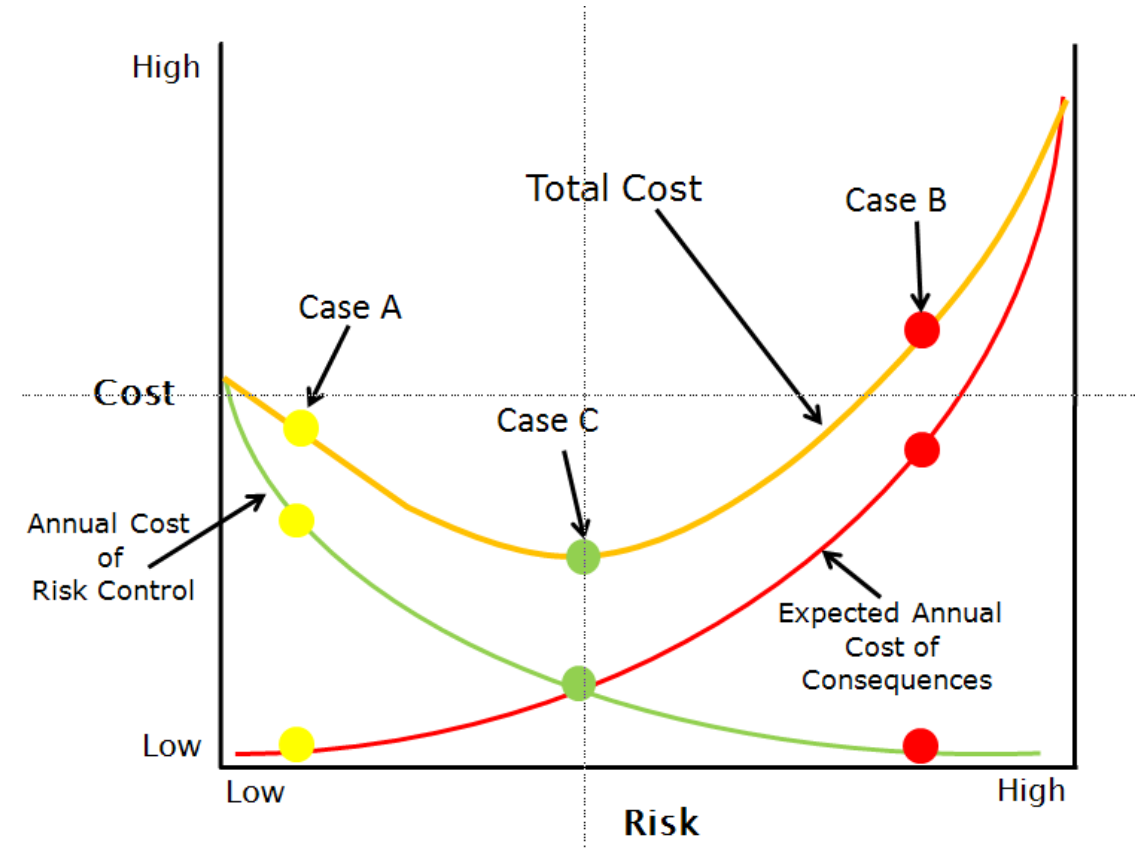

Figure 1 Risk-cost relationship (adapted from Viner, 2002)

Referring to Figure 1:

- When greater investment is made into risk control, the expected cost of losses is significantly lower (Case A).

- When investment in risk control is minimal (Case B), the expected losses can be severe.

- Based on this risk-cost approach, the design with the lowest total cost (compared to the other options) can then be considered the optimum design (Case C). However, due to practical considerations, the optimum design does not necessarily correspond with the lowest point on the total cost curve.

For a tabular stope mining layout, this design analysis can be carried out for different support systems on a single panel or for a ground control district. Common current practice is that rock engineering practitioners carry out stope designs based only on the cost of risk control. However, the total risk-cost approach gives a more comprehensive basis for comparing the risk associated with each support system.

This comprehensive $\mathrm{R} / \mathrm{C}$ approach to design will assist in answering the questions:

- How much support is too much support?

- What are the impacts of installing minimal or substandard support? 
- What is the cost of failure of a given support system?

While the risk mitigation cost is well understood and applied by rock engineers, the expected costs of consequences of rockfalls, and hence the total risk costs, are not quantified. The expected cost of consequences for a design can be expressed by the general equation:

\section{Expected annual cost of consequences $=$ \\ Rockfall annual frequency of occurrence $x$ Cost of consequences}

It is therefore critical to identify and quantify the consequences of rockfalls and the possible annual frequency of occurrence. This frequency is the probability of failure for a rockfall of a given size. These concepts are further developed in the next section.

\section{2 Annual frequency of rockfalls}

Annual frequency of occurrence of rockfalls is determined for rockfalls of differing size distributions. The method applied depends on the data available, that is, whether rockfall dimension data or joint properties data are available. When only rockfall dimension data are available, rockfall lengths are grouped into bins and the frequency of falls in each bin determined based on the rockfall database. When no rockfall records are applicable, stochastic probabilistic methods can be applied to joint properties to determine possible keyblocks and their corresponding probability of failure (e.g. Tyler et al., 1991; Beauchamp et al., 1998; Esterhuizen, 2003; Gumede, 2006; Stacey, 2007; Dunn et al., 2008). Both methods provide a rockfall frequency versus rockfall size relationship which can be determined over a given period of mining.

\section{3 Consequences associated with rockfalls}

Consequences of rockfalls can be divided into direct and indirect consequences. Indirect consequences are the result of the direct consequences. Table 1 (Joughin, 2008) provides a list of consequences drawn up from research and workshops involving experienced mining personnel from across the South African mining industry. This list was used in constructing the framework for quantifying the cost of consequences.

Several approaches have been used to determine the economic consequences of rockfall accidents. Baecher (1981), Chowdhury and Flentje (1998), Joughin (2008), Duzgun and Einstein (2004) and Marx (1996) present different approaches for quantifying the costs of the consequences of excavation damage. However, only Marx (1996) quantifies the costs of individual consequences of rockfalls. His approach does not take into account the cost implications of mandatory mine closures when accidents occur, since the legal framework associated with such closures was only implemented in 2006.

The proposed methodology for determining the cost of consequences is based on first establishing a generic framework for capturing the location, size of the fall of ground (FOG), the remedial action taken and the resulting consequences. This framework has multiple scenarios and is best presented in an event tree format, as shown in Figure 2 for accidents and injuries, and in Figure 3 for stope damage consequences.

Rockfalls can occur in the gully, and in face or back areas as indicated in the event tree. As shown in Figure 3, for falls in the face area the size of the rockfall determines the remedial action taken and hence the losses from the consequences. Common losses stem from production loss while cleaning up and re-supporting or re-establishing the panel or re-deploying personnel; dilution; actual cost of re-supporting; loss of reserve; and loss of sweepings revenue. The determination of these costs is explained in the sub-sections below. 
Table 1 Direct and indirect consequences associated with rockfalls

\begin{tabular}{|c|c|}
\hline Direct Consequences & Indirect Consequences \\
\hline \multirow[t]{11}{*}{ Injuries and fatalities } & $\begin{array}{l}\text { Excessive individual risk exposure for personnel (evaluate risk on probability of } \\
\text { failure versus number of fatalities graph - F-N graph). }\end{array}$ \\
\hline & $\begin{array}{l}\text { Temporary mine closure imposed by the department of Minerals and Energy } \\
\text { (Section 54). }\end{array}$ \\
\hline & Medical and rescue operation costs. \\
\hline & Wages and compensation. \\
\hline & Investigation and inquiries: cost of professional time. \\
\hline & Re-training: cost of re-training new employees. \\
\hline & SIMRAC levies. \\
\hline & Legal costs: (determined from precedent practice). \\
\hline & Insurance premiums: increase due to accident record). \\
\hline & Industrial action: difficult to quantify. \\
\hline & $\begin{array}{l}\text { Stakeholder resistance (reputation, share price and cost of capital): difficult to } \\
\text { quantify. }\end{array}$ \\
\hline \multirow{4}{*}{$\begin{array}{l}\text { Damage to equipment } \\
\text { and machinery (mobile } \\
\text { and fixed) }\end{array}$} & Loss of production: only production affected by equipment loss. \\
\hline & Cost of re-deployment of machinery and personnel to maintain production. \\
\hline & Replacement costs: large rockfalls. \\
\hline & Cost of repairs: depends on extent of damage (size of rockfall). \\
\hline \multirow{9}{*}{$\begin{array}{l}\text { Damage to excavations } \\
\text { (access excavations and } \\
\text { stopes) }\end{array}$} & Loss of reserves: net present value of lost reserves. \\
\hline & Loss of production (production shortfall). \\
\hline & Replacement of access excavation. \\
\hline & Rehabilitation of stopes. \\
\hline & Dilution (in stopes). \\
\hline & Re-deployment of machinery and personnel to maintain production. \\
\hline & Clean up operations: (depends on size of rockfall). \\
\hline & Insurance premiums: (Increase due to claims). \\
\hline & $\begin{array}{l}\text { Stakeholders resistance (reputation, share price and cost of capital): difficult to } \\
\text { quantify. }\end{array}$ \\
\hline
\end{tabular}




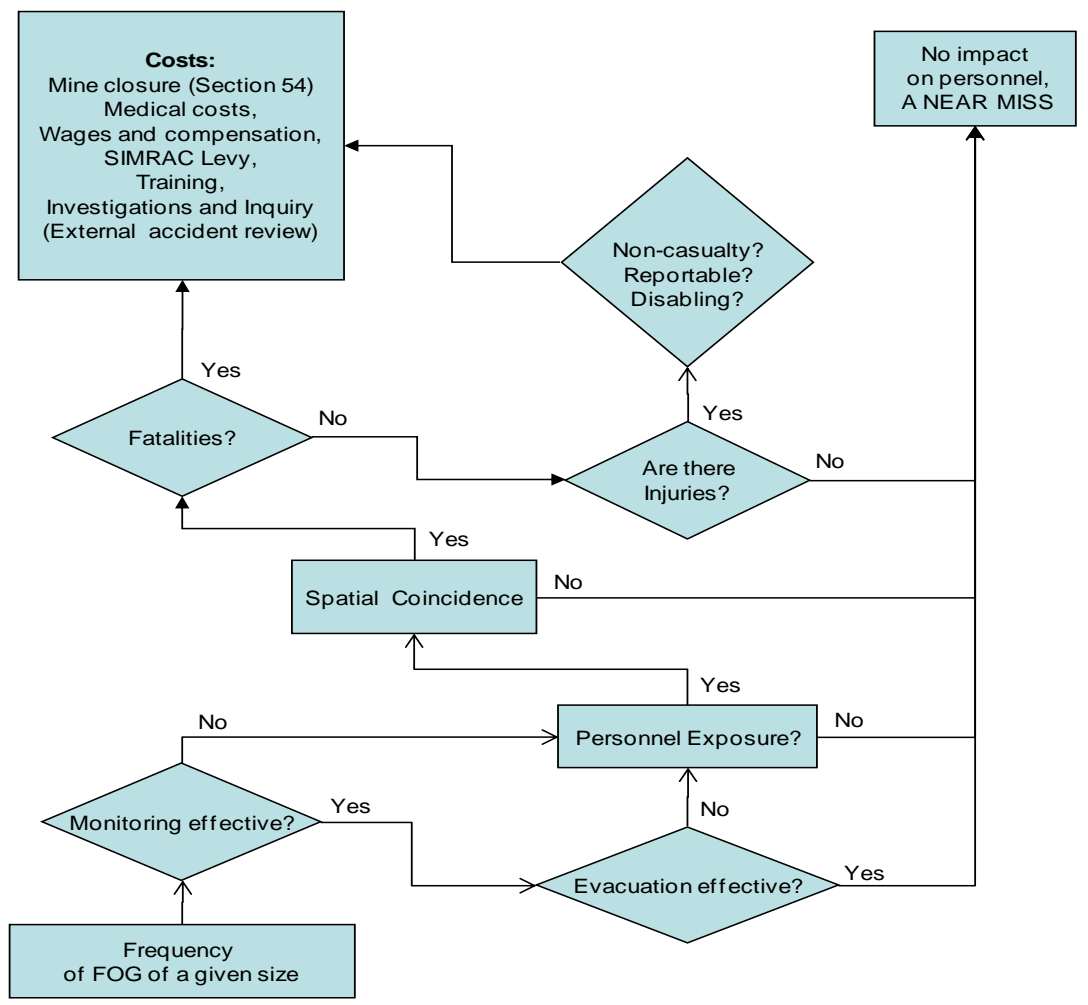

Figure 2 Event tree associated with accidents

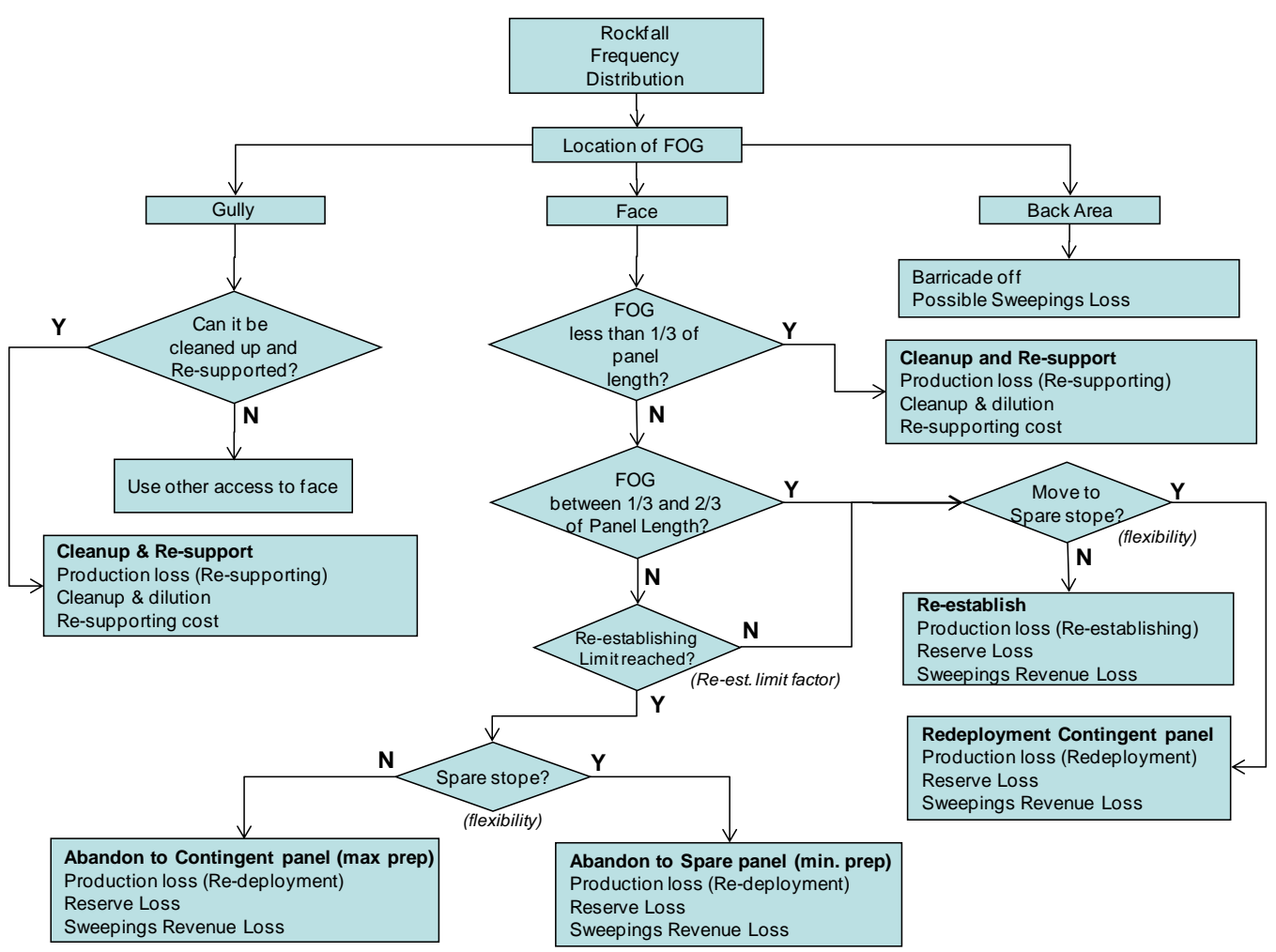

Figure 3 Event tree for consequences of stope damages

\section{3. 1 Clean up and dilution cost}

Small rockfalls are cleaned up with the ore, and hoisted to the processing plant. The rockfall is assumed to be waste rock, hence the cost of transportation and processing of waste material is termed dilution cost. 
Cleaning up the FOG requires labour. However, no additional labour is usually required to clean up small FOGs. The labour cost is therefore viewed as a fixed cost and is not considered in this methodology.

Total dilution cost (in South African Rands $(\mathrm{R})$ ) is determined as follows:

$$
\text { Total dilution cost }(\mathrm{R})=\text { Dilution cost }(\mathrm{R} / \mathrm{t}) \times \text { FOG size }(\mathrm{t})
$$

where:

Dilution cost $(\mathrm{R} / \mathrm{t})=$ (vertical cost + horizontal cost + processing cost $) /($ tonnes mined and processed $)$.

\section{3. 2 Re-supporting cost}

It is assumed that when a rockfall greater than $1 \mathrm{~m}$ in length but less than a third of the panel length occurs, the area has to be re-supported in order to make the panel safe. This is done by installing the same support pattern with increased support density or by using a different support system. The unit cost for re-supporting can therefore be determined. The costs of storage, transportation and installing are not included unless a new support system which requires new infrastructure and personnel is being applied. The labour required for transporting and installing support is considered a fixed cost.

The total re-supporting cost equation is given as:

Total re-supporting cost $=$

Area to be re-supported $x$ Support density $x$ Cost per installed unit

where:

Area to be re-supported = area of FOG $\times$ Re-supporting area factor.

\section{3. 3 Cleaning up and re-supporting production loss}

This loss corresponds with the time spent cleaning up and re-supporting and will vary depending on the size of the FOG, and the type and availability of the recommended support units. It is expressed as:

\section{Production loss $=$}

Total days required to clean and re-support $x$ Profit loss $\left(\mathrm{R} / \mathrm{m}^{2}\right) \times$ Panel tonnage/day

where:

Profit loss $=$ revenue (cost of consumables + cost of transport + processing cost $)$.

\section{3. 4 Sweepings loss}

"Sweepings" describe broken ore which carries high mineral grade, and is therefore a source of revenue. When large rockfalls occur in the face area, in some situations the area becomes inaccessible or unsafe to sweep. As a result the sweepings are not claimable, hence the term sweepings loss. The total sweepings loss is determined as:

$$
\text { Total sweepings loss }=\text { Sweepings loss per } \mathrm{m}^{2} \mathrm{x} \text { Expected sweepings area }
$$

where:

$\begin{array}{ll}\text { Sweepings loss } & =\text { unadjusted sweepings loss } \mathrm{x} \text { height factor } \mathrm{x} \text { density factor } \\ \text { Sweepings loss } / \mathrm{m}^{2} & =\text { (revenue }- \text { processing cost }) / \text { area mined } \\ \text { Height factor } & =\text { sweepings height/stoping height } \\ \text { Density factor } & =\text { sweepings loose density/in situ rock density } \\ \text { Expected sweepings area } & =\text { FOG area }\left(\mathrm{m}^{2}\right)+\left(\text { FOG area }\left(\mathrm{m}^{2}\right) \times \text { sweepings area factor }\right)\end{array}$




\section{3. 5 Production loss due to re-establishing or re-deployment}

Loss of production occurs when large FOG occur. In this methodology it does not include the loss of production due to mandatory closure of the mine by the government inspectorate.

Total production loss $=$

(Re-deployment production loss x Flexibility) + (Re-establishing production loss $x$ (100\% Flexibility))

Re-deployment production loss $=$ Total days to re-deployment $\times$ Production loss $x$ Panel $t / d a y$

Re-establishing production loss $=$

Re-deployment days $x$ (Expected panel production -

Re-establishing production) $x$ Production loss $x$ Flexibility

\section{3. 6 Reserve loss}

If a panel is being re-established or being abandoned, a reserve loss can occur. The loss of reserves results in the shortening of the life of the mine. This has an overall impact on the net present value (NPV) of the operation. This effect is negative and hence is a net present cost.

\section{Case study}

The case study is based on a South African narrow tabular conventional mining operation. Scattered breast mining is conducted on $30 \mathrm{~m}$ panels with raise lines $180 \mathrm{~m}$ apart. Strike gullies are used as access ways to the face, and for cleaning, and material transport.

The input parameters required to determine the costs of rockfall consequences were categorised as general mining parameters, accident statistics, financial information, support standard and costs. These will be described in the following sections.

\section{1 General mining parameters}

The general mining inputs are classified as geometric, rock mass, and productivity parameters. The aspects considered under each parameter are given in Table 2 . The values presented were obtained from the mines mining standards and discussions with the mining personnel.

Figure 4 shows an illustration of the stope layout and relevant dimensions.

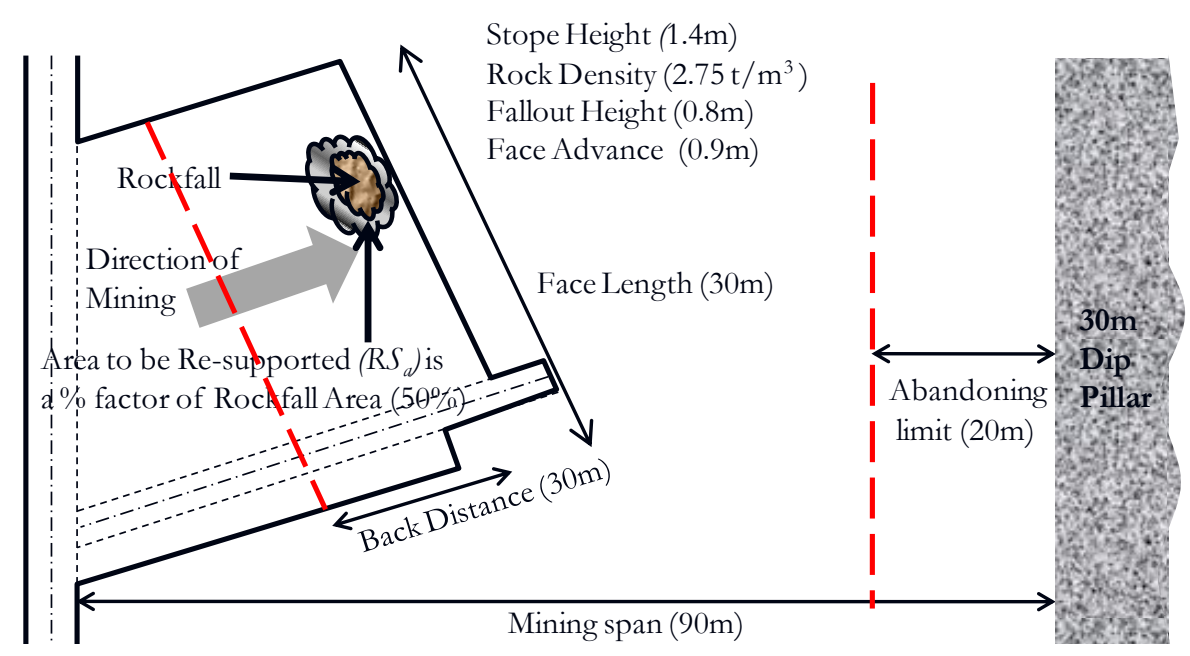

Figure 4 Stope layout and mining parameters 
Table 2 General mining parameters

\begin{tabular}{lc}
\hline Geometry & \\
\hline Face length $(\mathrm{m})$ & 30 \\
Advance per blast $(\mathrm{m})$ & 0.9 \\
Stoping height $(\mathrm{m})$ & 1.4 \\
Mining span $(\mathrm{m})$ & 90 \\
Abandoning limit $(\mathrm{m})$ & 20 \\
Re-supporting factor $(\%)$ & 50 \\
\hline Rock Mass & \\
\hline Rock density $\left(\mathrm{t} / \mathrm{m}^{3}\right)$ & 3.1 \\
Average mineral grade $(\mathrm{g} / \mathrm{t})$ & 3.7 \\
Bulk density $\left(\mathrm{t} / \mathrm{m}^{3}\right)$ & 1.83 \\
\hline Productivity & \\
\hline Working days per month & 23 \\
Blasts per month & 18 \\
\hline
\end{tabular}

\section{2 Support inputs}

Support cost inputs are summarised in Table 3.

Table 3 Support costs

\begin{tabular}{lc}
\hline Material & Cost \\
\hline Wedge props $(1.6 \times 1.8 \mathrm{~m})$ & $81.44 \mathrm{R} /$ unit \\
Wedge props $(1.8 \mathrm{~m} \times 180 \mathrm{~mm})$ & $87.98 \mathrm{R} /$ unit \\
Madoda 180 ST pre-stressing unit & $37.90 \mathrm{R} /$ unit \\
SS 39 split sets $(1,800 \mathrm{~mm})$ & $32.33 \mathrm{R} /$ unit \\
Timber composite pack $(1.1 \times 1.1 \mathrm{~m})$ & $1,513.18 \mathrm{R} /$ pack \\
Backfill & $36.54 \mathrm{R} / \mathrm{m}^{2}$ \\
\hline
\end{tabular}

\section{3 Financial information}

The financial data was obtained from the mine's Annual Report, shaft finance departments and discussions with accounts personnel. Important derivatives from the data are the revenue earned over a period, the costs of mining consumables and the processing costs. From these, the dilution cost, production loss and the sweepings loss were determined.

\section{3. 1 Dilution costs}

While dilution cost is the cost of horizontal and vertical transport and processing the waste rock, the cost of vertical and horizontal transport could not be extracted from the financial data provided. The processing cost comprised of concentrating and smelting and the refining operations cost. The dilution cost per tonne, shown in Table 4, was calculated to be $\mathrm{R} 96.67 / \mathrm{t}$. 
Table 4 Dilution costs

\begin{tabular}{lr}
\hline Description & Value/Quantity \\
\hline Annual tonnage milled ( $\mathrm{t}$ ) & $15,855,000$ \\
Annual concentration/smelting cost (R) & $1,057,000,000$ \\
Annual refining operations cost (R) & $476,000,000$ \\
Annual processing cost (R) & $1,533,000,000$ \\
Dilution cost (R/t) & 96.67 \\
\hline
\end{tabular}

\section{3. 2 Production loss}

Table 5 shows the parameters required to determine the production loss. The revenue and processing costs per tonne were determined from the annual report information. The consumables cost per tonne was then determined from shaft data. The resulting production loss was $\mathrm{R} 1,127 / \mathrm{t}$.

Table 5 Production loss

\begin{tabular}{lr}
\hline Parameters & \multicolumn{1}{c}{ Value } \\
\hline Annual tonnage milled $(\mathrm{t})$ & $15,855,000$ \\
Annual revenue (R) & $20,889,000,000$ \\
Annual processing cost (R) & $1,533,000,000$ \\
Revenue per tonne (R/t) & $1,317.50$ \\
Tonnes mined per month (shaft) (t/month) & 86,000 \\
Cost of consumables (shaft) (R) & $8,092,054$ \\
Cost of consumables per tonne (R/t) & 94.09 \\
Processing cost per tonne (R/t) & 96.67 \\
Production loss (R/t) & 1,127 \\
\hline
\end{tabular}

\section{3. 3 Sweepings loss}

The adjusted sweepings loss is $\mathrm{R} 727 / \mathrm{m}^{2}$ mined. Table 6 shows the data used in determining this value.

Table 6 Determination of sweepings loss

\begin{tabular}{lr}
\hline Description & \multicolumn{1}{c}{ Value } \\
\hline Annual square metres mined $\left(\mathrm{m}^{2}\right)$ & $3,391,679$ \\
Annual revenue $(\mathrm{R})$ & $20,889,000,000$ \\
Annual processing cost $(\mathrm{R})$ & $1,533,000,000$ \\
Loose density $\left(\mathrm{t} / \mathrm{m}^{3}\right)$ & 1.83 \\
In situ density $\left(\mathrm{t} / \mathrm{m}^{3}\right)$ & 3.1 \\
Average sweepings height $(\mathrm{m})$ & 0.2 \\
Stope height $(\mathrm{m})$ & 1.0 \\
Sweepings loss $\left(\mathrm{R} / \mathrm{m}^{2}\right)$ & 727 \\
\hline
\end{tabular}




\section{4 Rockfall data}

The rock engineering department maintains a rockfall database which records rockfall accidents. This database captures the section, date, dimension, volume, tonnage, and strike and dip length of the FOG. These data are comprehensive and applicable to the purposes of this case study. Stochastic probabilistic methods can also be applied to joint properties to determine keyblocks and the corresponding probability of failure of such blocks. No joint data were available on the mine and hence data from a neighbouring mine with a similar geological environment were used. The joint input parameters are listed in Table 7. The specific gravity for the blocks was taken to be $3,100 \mathrm{~kg} / \mathrm{m}^{3}$. The mean friction angle for all the joints was set at $30^{\circ}$ with a standard deviation of $10^{\circ}$.

Table 7 Jointing input parameters

\begin{tabular}{|c|c|c|c|c|c|c|c|c|}
\hline \multirow{2}{*}{$\begin{array}{c}\text { Joint } \\
\text { Set }\end{array}$} & \multirow{2}{*}{$\begin{array}{l}\text { Dip } \\
\text { (deg.) }\end{array}$} & \multirow{2}{*}{$\begin{array}{c}\text { Dip } \\
\text { Direction } \\
\text { (deg.) }\end{array}$} & \multicolumn{3}{|c|}{ Spacing (m) } & \multicolumn{3}{|c|}{ Length ( $\mathrm{m})$} \\
\hline & & & Mean & Min & Max & Mean & Min & Max \\
\hline $\mathrm{J} 1$ & 77 & 215 & 0.9 & 0.2 & 3.0 & 2.2 & 1.5 & 3.0 \\
\hline$J 2$ & 50 & 266 & 0.8 & 0.2 & 2.0 & 3.5 & 1.5 & 10 \\
\hline $\mathrm{J} 3$ & 60 & 22 & 1.0 & 0.3 & 10 & 3.8 & 1.5 & 15 \\
\hline $\mathrm{J} 4$ & 62 & 78 & 1.0 & 0.1 & 10 & 3.4 & 1.5 & 10 \\
\hline $\mathrm{J} 5$ & 89 & 155 & 1.0 & 1.0 & 10 & 3.0 & 1.5 & 8 \\
\hline $\mathrm{J} 6$ & 63 & 117 & 0.3 & 0.3 & 10 & 2.9 & 1.5 & 7 \\
\hline
\end{tabular}

Using these joint data as inputs, a probabilistic keyblock analysis package available in the South African mining industry - JBLOCK (Esterhuizen, 2003) - was used to generate possible keyblocks in the excavation geometry. Support elements are introduced into this geometry, based on the designed support patterns, and the software then evaluates the effectiveness of each support system in preventing rockfalls.

\section{5 Results of individual costs of rockfalls}

The total expected costs per rockfall length for all the rocks are illustrated in Figure 5. From the graph it is clear that for rockfall lengths exceeding $10 \mathrm{~m}$, the re-establishing cost is the major cost driver. Re-establishing a $10 \mathrm{~m}$ length of panel costs approximately $\mathrm{R} 750,000$, increasing to $R 1,900,000$ for a full panel collapse $(28.5 \mathrm{~m})$. Reserves lost are about $R 80,000$ for a $10 \mathrm{~m}$ fall, and increase to $\mathrm{R} 400,000$ for a $28.5 \mathrm{~m}$ fall. The sweepings loss contribution to the total cost is lower at $\mathrm{R} 300,000$ for the $28.5 \mathrm{~m}$ rockfall. This graph shows that rockfalls less than $10 \mathrm{~m}$ in length cost very little in terms of damage to excavation costs.

In Figure 6, no data on falls above $10 \mathrm{~m}$ are included. Production lost due to cleaning up and re-supporting is the major cost contributor, followed by clean up and dilution and then re-supporting. The production loss increases as the rockfall size increases. Typically a $9 \mathrm{~m}$ rockfall has a production loss of $R 54,000$, a clean up cost of $R 22,000$ and a re-supporting cost of $R 7,000$. 


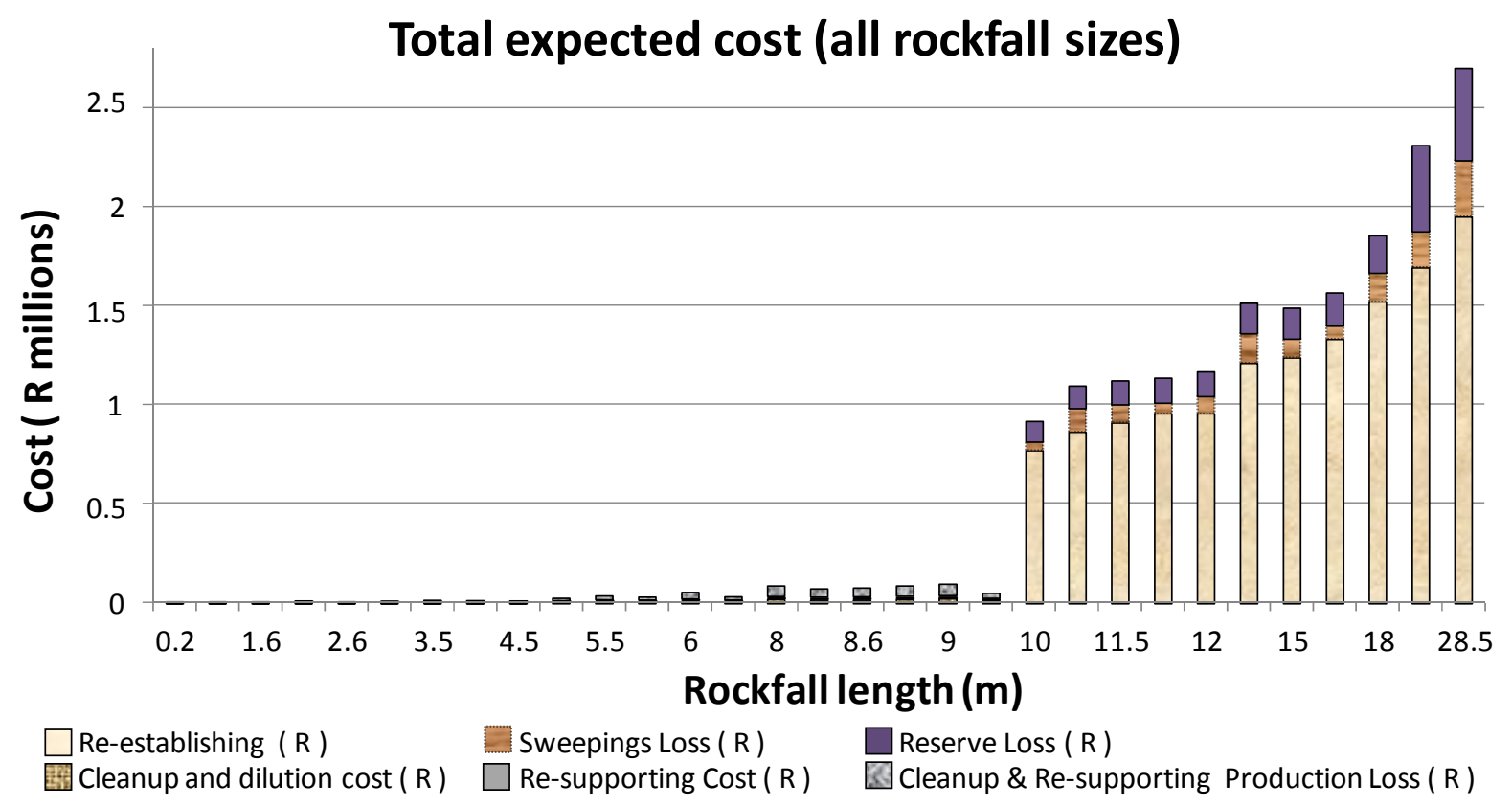

Figure 5 Total expected costs (all sizes)

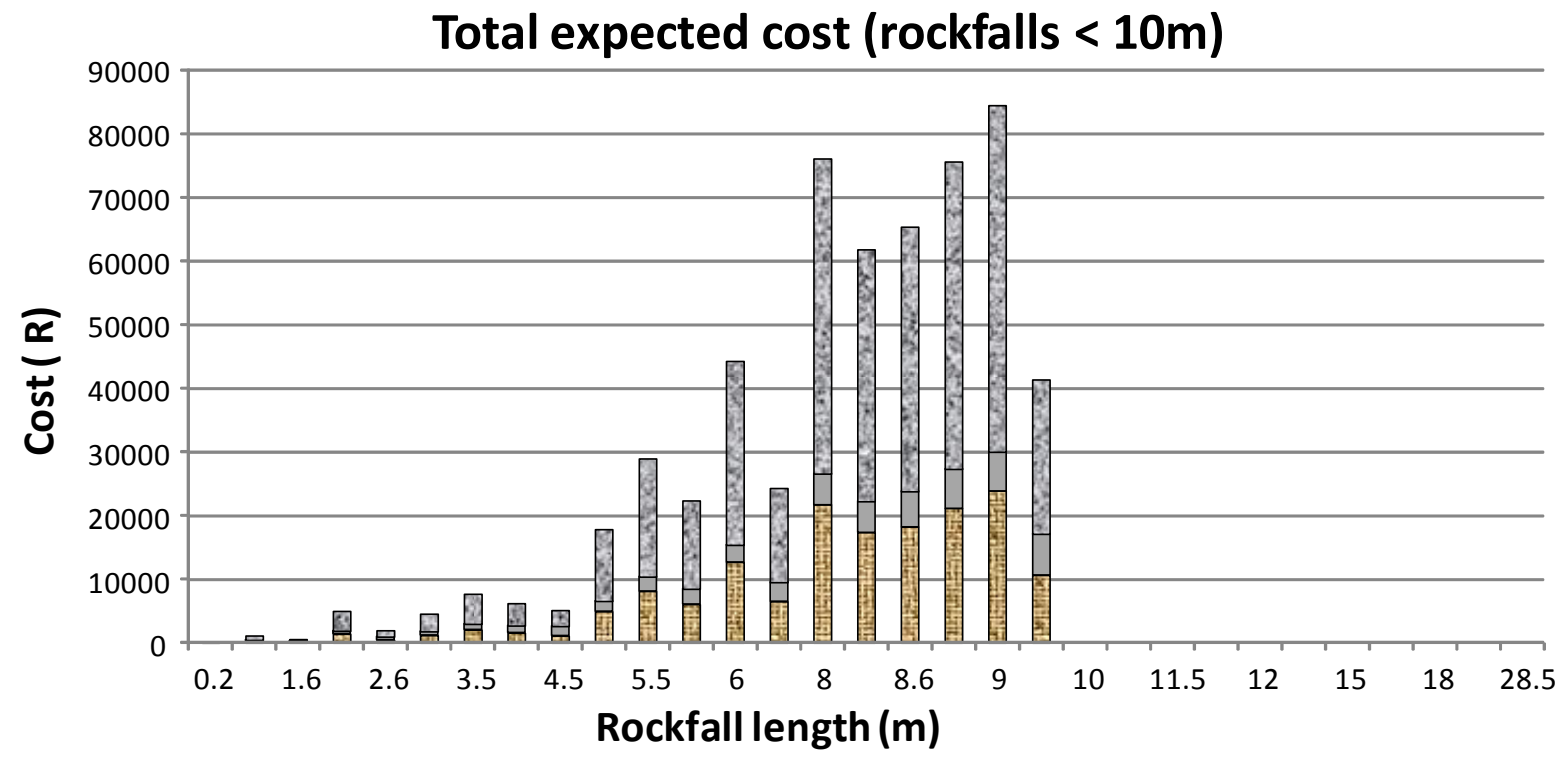

国Cleanup and dilution cost ( R ) $\square$ Re-supporting Cost (R) $\quad$ Cleanup \& Re-supporting Production Loss ( R )

Figure 6 Total costs (rockfalls $<10 \mathrm{~m}$ )

\section{3. $6 \quad \mathrm{R} / \mathrm{C}$ analysis}

Two scenarios were considered. Scenario A is a design with elongates only in the back area. Scenario B on the other hand is composed of a denser elongate pattern, and timber packs in the back area. Clearly, it is expected that type A support will cost less than type B.

The risk mitigation cost in scenario A is $R 409,199$ per panel whereas for scenario $B$ it is $R 976,370$ per panel. It is therefore apparent that there is a cost saving of $R 567,170$ per panel if scenario $A$ is used. 
Table 8 Comparison of support types

\begin{tabular}{lll}
\hline & Support Type A & Support Type B \\
\hline Face & $1.5 \times 1.0$ m camlock props & $1.5 \times 1.0 \mathrm{~m}$ camlock props \\
Back area & $\begin{array}{l}\text { No timber packs. Elongates at } 2.0 \times 2.0 \mathrm{~m} \\
\text { spacing }\end{array}$ & $\begin{array}{l}\text { Timber packs at } 5 \times 3 \mathrm{~m} \text { spacing. Elongates at } \\
1.5 \times 1.0 \mathrm{~m} \text { spacing }\end{array}$ \\
Gully & $\begin{array}{l}2 \mathrm{~m} \text { on strike timber pack spacing. Split } \\
\text { sets at } 1 \times 1 \mathrm{~m} \text { grid spacing }\end{array}$ & $\begin{array}{l}2 \mathrm{~m} \text { on strike timber pack spacing. Split sets } \\
\text { at } 1 \times 1 \mathrm{~m} \text { grid spacing }\end{array}$ \\
\hline
\end{tabular}

In Table 9, comparative statistics from the probabilistic keyblock simulation are presented. Though a larger area was simulated in B, A has a higher percentage of failed key blocks $(61 \%)$. A has a larger average failure volume, $122 \mathrm{~m}^{3}$, whereas $B^{\prime} \mathrm{s}$ average is $53 \mathrm{~m}^{3}$. Figure 7 shows the distribution of the volumes of the rockfalls generated for $A$ and $B$ respectively. This distribution was applied in the $R / C$ software.

Table 9 Statistics from probabilistic keyblock software

\begin{tabular}{lcc}
\hline & Scenario A & Scenario B \\
\hline Area simulated & $9,120 \mathrm{~m}^{2}$ & $9,420 \mathrm{~m}^{2}$ \\
Percentage of failed keyblocks & $61 \%$ & $50 \%$ \\
Average rockfalls per 1,000 $\mathrm{m}^{2}$ exposed & 2,141 & 1,810 \\
Average failure volume & $122 \mathrm{~m}^{3}$ & $53 \mathrm{~m}^{3}$ \\
\hline
\end{tabular}

\section{6. $1 R / C$ results for the two scenarios}

The costs of risk mitigation, injury, damage to excavation and reserve losses and the NPV for the two scenarios (Scenarios A and B) are determined for a single panel. Injury costs include the cost of temporary mine closure, medical, wages and compensation, investigation and safety research levies. Damage costs include production loss, re-establishment of panels, re-deployment of personnel, rehabilitation (re-supporting), clean up and dilution costs.

The factors not included in the injury or damage costs were either too complex to quantify or no meaningful data were obtained to quantify them. Due to these limitations or the assumptions made in the methodology, the costs presented could be somewhat understated. Therefore, the numbers presented can be taken to be lower bound estimates of the cost.

The expected injury cost is R 193,384 per panel scenario A and R 121,145 for scenario B. Installing more support in a panel (Scenario B) therefore reduces the expected injury cost by $R 72,239$.

The expected damage to excavation cost is $R 16,868,175$ per panel for scenario $A$ and $R 7,399,644$ per panel for scenario $B$. An inadequately supported panel (scenario A) results in damage worth $R$ 9,468,531 more than a panel with more support (scenario B).

The NPV for the stope over a five year period at a discount rate of $12 \%$ is $R 63,000,000$ per panel for scenario A (Figure 7) and R 31,000,000 for scenario B (Figure 8). 


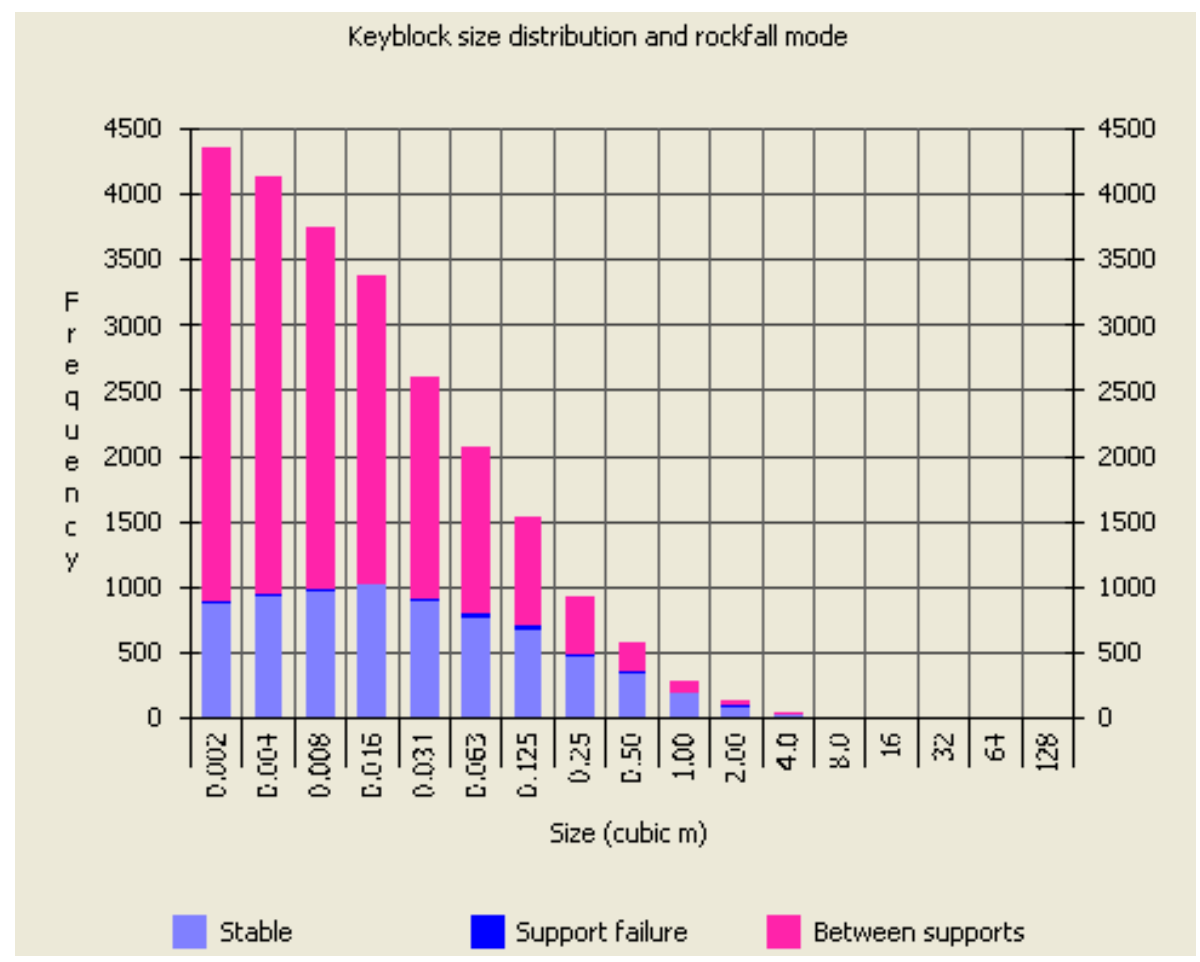

Figure 7 Scenario A rockfalls

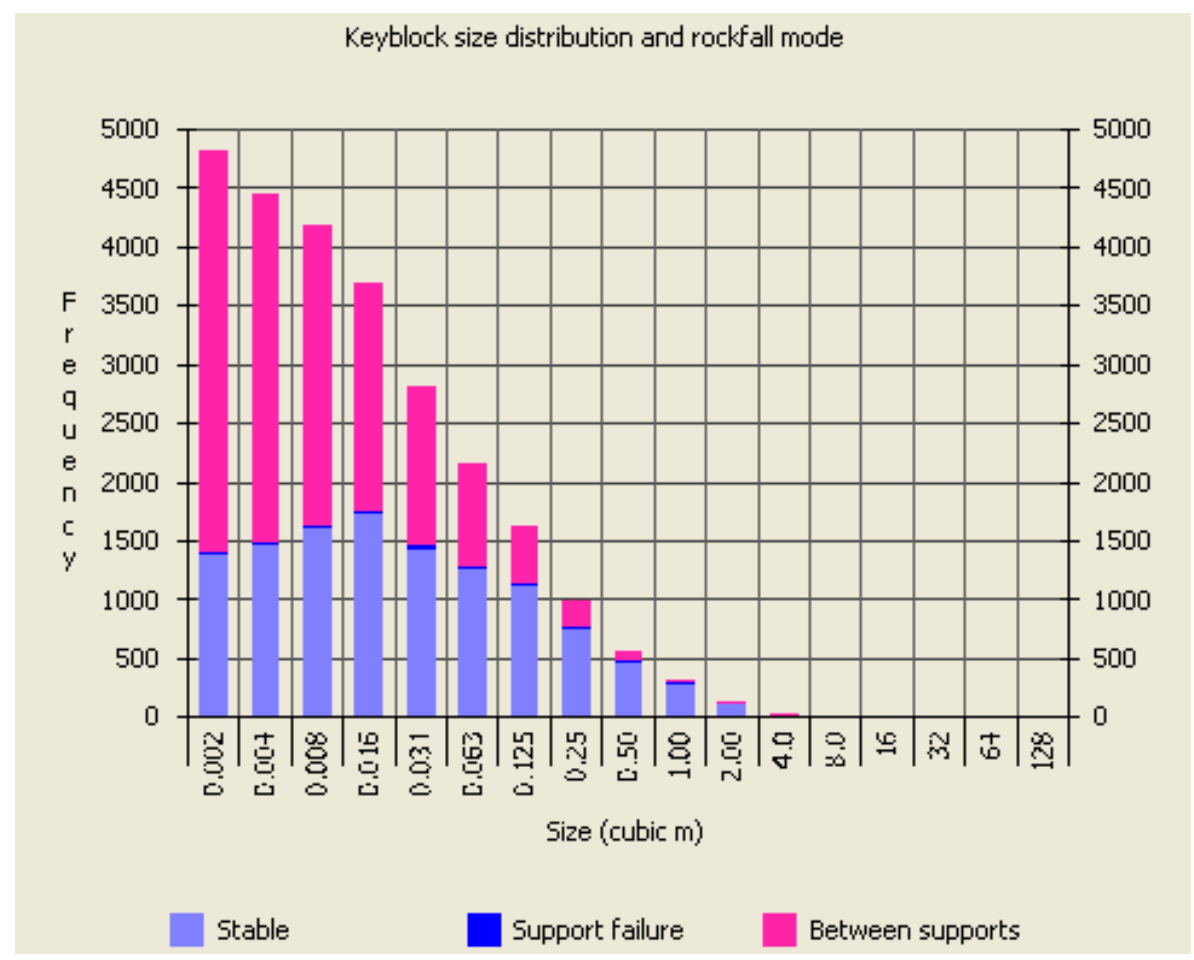

Figure 8 Scenario B rockfalls

\section{Conclusions}

There are few published or documented studies on the quantification of financial consequences associated with rockfalls in South African narrow tabular mining operations. The methodology and results presented in this paper are believed to be the most comprehensive work on this subject to date. The methodology involves the determination of the probability of occurrence of rockfalls and the quantification of the costs associated with such events. 
The application of the methodology to a case study has illustrated that the tactical approach of cost cutting (minimising support costs) may have short-term financial benefits, but the strategic approach of investing in better support, while more costly, actually generates much greater value for the mine in the longer-term. Clearly, there is greater safety benefit with the better support, indicating that investing in safety is likely to result in much greater financial benefit to a mine. With this design technology available, mine management is in a position to plan mining operations on a strategic basis instead of the tactical or cost cutting basis that is in common use at present.

\section{Acknow l edgements}

The authors thank Rock Engineering and Mine Management, and staff, of Anglo Gold Ashanti, Mponeng Gold Mine and Impala Platinum for their cooperation in this work. Special thanks also go to the Safety in Mines Research Committee (SIMRAC) 'Elimination of rockfalls' Track B team, Mike Roberts, Anthony Jager, Dave Roberts and Roger Stewart for their constructive input into the development of the methodology.

\section{References}

Baecher, G.B. (1981) Risk Screening for Civil facilities: Massachusetts Institute of Technology, Department of Civil Engineering, CER, Vol. 81, pp. 90-110.

Baecher, G.B. and Christian, T.J. (2003) Reliability and Statistics in Geotechnical Engineering, John Wiley and Sons, West Sussex, England.

Barton, N., Lien, R. and Lunde, J. (1974) Engineering classification of rock masses for the design of tunnel support, Rock Mechanics, Vol. 6 (4), pp. 189-236.

Bawden, W.F. (2008) Risk Assessment in Strategic and Tactical Geotechnical Underground Mine Design, in Proceedings from 42nd US Rock Mechanics Symposium and 2nd US-Canada Rock Mechanics Symposium, held in San Francisco, 29 June-2 July 2008.

Beauchamp, K.J., Carvalho, J., Castro, L. and Morrison, D.M. (1998) Probabilistic Analysis for Ground Support for Underground Mines, CIM, Montreal.

Brummer, R.K. and Kaiser, P.K. (1995) Risk-Cost Benefit Analysis for Support Design in Burst-Prone Mines, Transactions from Institute of Materials, Minerals and Mining, January-April 1995, Vol. 104, pp. A71-A75.

Carter, T.G. and Miller, R.L. (1995) Crown-pillar risk assessment-planning aid for cost effective mine closure remediation, Transactions from Institute of Materials, Minerals and Mining (Section A: Mining Technology), January-April 1995, Vol. 104, pp. A41-A57.

Chowdhury, R.N. and Flentje, P.N. (1998) A landslide database for landslide hazard assessment, in Proceedings 2nd International Conference on Environmental Management, M. Sivakumar and R.N. Chowdhury (eds), February 10-13, Wollongong, Australia, Elsevier, London, pp. 1229-1239.

Christian, J.T. (2004) Geotechnical Engineering Reliability: How well do we know what we are doing?, Journal of Geotechnical and Geoenvironmental Engineering, ASCE, ISSN 10900241/2004/10-985-1003.

Contreras, L.F., LeSeur, R. and Maran, J. (2006) A case study of risk evaluation at Cerejon Mine, in Proceedings from International Symposium on Stability of Rock Slopes in Open Pit and Civil Engineering, April 2006, Cape Town, South Africa, South African Institute of Mining and Metallurgy, pp. 181-210.

Davies, M.P. (1997) Potential problem analyses: A practical risk assessment technique for the mining industry, CIM Bulletin, April 1997, Vol. 90, pp. 49-52.

Dunn, M.J., Earl, P.J. and Watson, J. (2008) Support design using probabilistic keyblock methods, in Proceedings 6th International Symposium on Ground Support in Mining and Civil Engineering Construction, SAIMM, SANIRE and ISRM.

Duzgun, H.S.B. and Einstein, H.H. (2004) Assessment and Management of rockfall risks in Underground coal mines, Safety Science Vol. 42, pp. 23-41.

Einstein, E.E. (1996) Risk and risk analysis in rock engineering, Tunnell, Underground Space Technology, Vol. 11 (2), pp. 141-155.

Einstein, H.H. (2003) Uncertainty in Rock Mechanics and Rock Engineering-Then and Now, ISRM-Technology Roadmap for Rock Mechanics, SAIMM

Esterhuizen, G.S. (2003) JBLOCK user manual, Pretoria.

Gumede, H. (2006) Development of data sets on joint characteristics and consideration of associated instability for a typical South African gold mine, MSc Eng Dissertation, University of the Witwatersrand.

Joughin, W.C. (2008) A preliminary model for quantifying the risk of rockfalls and evaluating the benefits of safety spending.

Laubscher, D.H. (1990) A geomechanics classification system for the rating of rock mass in mine design, in the Journal of South African Institute of Mining and Metallurgy, Vol. 90, No. 10, pp. 257-273.

Marx, C. (1996) An activity based costing approach to fall of ground accidents in a South African gold mine, Potchefstroom: PU vir $\mathrm{CHO}$ (Dissertation-MBA).

Peck, R.B. (1969) The observational method in applied soil mechanics-9th Rankine Lecture, Geotechnique, Vol. 19, pp. $171-187$. 
Pine, R.J. and Arnold, P.N. (1996) Application of risk assessment methods to underground excavations, in Proceedings Eurock'96, Turin, Italy, G. Barla (ed), Balkema, pp. 1189-1196.

Pine, R.J. and Thin, I.G. (1993) Probabilistic risk assessment in mine pillar design, in Proceedings Innovative Mine Design for the 21st Century, W.F. Bawden and J.F. Archibald (eds), Balkema, pp. 363-373.

Potvin, Y. (1998) Empirical stope design in Canada, PhD Thesis, University of British Columbia.

Potvin, Y. and Hadjigeorgiou, J. (2001) The stability graph method for open stope design, W.A. Hustrulid and R.L. Bullock (eds), in Underground mining methods: engineering fundamentals and international case studies, Society for Mining Metallurgy and Exploration Inc, SME, pp. 513-520.

Stacey, T.R. (2006) Design-A Strategic Issue, in Proceedings 2nd International Seminar on Strategic versus Tactical Approaches in Mining, Perth, Western Australia, 8-10 March 2006, Australian Centre for Geomechanics, Section 4, 13 p.

Stacey, T.R. (2007) Is Rock Engineering Addressing Risk Appropriately?, Redefining the boundaries Part 2, Proceedings SANIRE 2007 Symposium, Free State, South Africa.

Summers, J. (2000) Analysis and Management of Mining Risk, in Proceedings MassMin 2000, G. Chitombo (ed), 29 October to 2 November 2000, Brisbane, Australia, Australasian Institute of Mining and Metallurgy, Melbourne, pp. 63-79.

Swart, A.H., Stacey, T.R., Wesseloo, J., Joughin, W.C., Le Roux, K., Walker, D. and Butcher, R. (2000) Investigation of factors governing the stability/instability of stope panels in order to define a suitable design methodology for near surface and shallow mining operations, Safety in Mines Research Advisory Committee (SIMRAC) final project report OTH501.

Tapia, A., Contreras, L.F., Jefferies, M.G. and Steffen, O. (2007) Risk evaluation of slope failure at Chuquicamata Mine, in Proceedings International Symposium on Rock Slope Stability in Open Pit Mining and Civil Engineering (Slope07), Yves Potvin (ed), 12-14 September 2007, Perth, Western Australia, Australian Centre for Geomechanics, Perth, pp. 477-496.

Terbrugge, P.J., Steffen, O.K.H., Wesseloo, J. and Venter, J. (2006) A risk consequence approach to open pit slope design, in Proceedings from International Symposium on Stability of Rock slopes in Mining and Civil Engineering Situations, Cape Town, April 2006, in the Journal of South African Institute of Mining and Metallurgy, pp. 81-96.

Tyler, D.B., Trueman, R. and Pine, R.J. (1991) Rockbolt support design using a probabilistic method of keyblock analysis, In Rock Mechanics as a Multidisciplinary Science, J.C. Roegiers (ed), Rotterdam, Balkema, pp. 1037-1047.

Vanmarcke, E.H. and Bohenblust, H. (1982) Methodology for integrated risk assessment for dams, MIT Research Report, Vol. 82, pp. 11-23.

Viner, H.C. (2002) Risk management lecture notes, School of Mining Engineering, Witwatersrand University.

Wong, W. (2005) How did that happen? - Engineering Safety and Reliability, Professional Engineering Publishing Limited, Edmonds, UK. 